\title{
ANALISIS USAHA TAMBAK IKAN BANDENG PADA DAERAH SEKITAR AKTIVITAS PERTAMBANGAN
}

\section{BUSINESS ANALYSIS OF MILK FISH POND IN AREA AROUND MINING ACTIVITIES}

\author{
Irmasila $^{1)}$, Lukman Yunus ${ }^{1)}$, Muhammad Aswar Limi ${ }^{1 *)}$ \\ ${ }^{1}$ Jurusan Agribisnis Fakultas Pertanian Universitas Halu Oleo Kendari 93232 \\ *Corresponding author: aswar_agribusiness@yahoo.com \\ irmasila17@gmail.com ; lukuyus@yahoo.com
}

\begin{abstract}
ABSTRAK
Penelitian ini bertujuan untuk melihat seberapa besar pendapatan yang dapat diperoleh melalui budidaya tambak bandeng di Kabupaten Konawe pada daerah sekitar aktivitas pertambangan. Kecamatan Bondoala merupakan salah satu sentra produksi bandeng terbesar dan terluas di Kabupaten Konawe. Oleh karena itu dipilih untuk penelitian. Pemilihan lokasi juga didasarkan pada kenyataan bahwa di Kecamatan Bondoala terdapat perusahaan pertambangan yang dekat dengan pemukiman masyarakat, yang akan berdampak pada kondisi tambak secara langsung maupun tidak langsung. Dalam penelitian ini digunakan 24 responden sebagai sampel. Analisis data deskriptif kuantitatif digunakan untuk menganalisis pendapatan usahatani tambak ikan bandeng. Hasil analisis menunjukkan pendapatan yang dihasilkan dalam satu musim tanam (enam bulan), budidaya tambak bandeng sebesar Rp 6.079.847.
\end{abstract}

Kata Kunci: Tambak Ikan Bandeng; Aktivitas Pertambangan; Kabupaten Konawe

\section{ABSTRACT}

This study aims to see how much income can be obtained through milkfish pond cultivation in Konawe Regency in the area around mining activities. Bondoala District is one of the largest and most comprehensive milkfish production centers in the Konawe Regency. Therefore it was selected for research. The location selection is also based on the fact that in the Bondoala District, there are mining companies close to community settlements, which will impact the condition of the ponds directly or indirectly. In this study, 24 respondents were used as samples. Quantitative descriptive data analysis was used to analyze the income of milkfish pond farming. The analysis results show that the income generated in one growing season (six months), milkfish pond cultivation is IDR6,079,847.

Keywords: Milkfish Pond; Mining Activities; Konawe Regency

\section{Pendahuluan}

Wilayah kelautan dan pesisir memiliki peranan terhadap kehidupan dan banyak digunakan masyarakat karena hampir sebagaian besar wilayah di indonesia merupakan daerah pesisir, sehingga sangat potensial diijadikan sebagai sumber mata pencaharian khususnya bagi nelayan pembudidaya. Budidaya perikanan terdiri dari budidaya payau, laut dan pantaimaka kegiatan memanfaatkan lahan tambak merupakan usaha budidaya tambak bandeng yang diharapkan mampu menopang target produksi nasional (Alikodra, 2005). Selain 
memiliki potensi perikanan yang cukup tinggi, Indonesia juga sangat potensial dalam kegiatan pertambangan nikel khususnya di Provinsi Sulawesi Tenggara. Potensi sumber daya mineral nikel di Provinsi Sulawesi Tenggara sangat besar, mencapai 97,4 miliar ton yang tersebar di 480 ribu hektar. Antara tahun 2008 dan 2015, operasi penambangan mineral nikel menyumbang 56,9 juta ton nikel, mengurangi sumber daya mineral nikel menjadi 97,3 miliar ton nikel. (Pusat Data dan Teknologi Informasi Energi dan Sumber Daya Mineral Kementerian Energi dan Sumber Daya Mineral, 2015).

Adanya aktivitas pertambangan akan memberikan dampak positif sekaligus menimbulkkan pengaruh negatif teutama bagi lingkungan hidup perusahaannya, semakin menurunnya kesuburan tanah, timbulnya debu dan kebisingan. Oleh sebab itu, untuk mengelola sumberdaya mineral nikel perlu adanya penerapan sistem pertambangan yang tepat dan sesuai, baik dilihat dari segi teknisi, sosial maupun ekonomis agar penerapannya dapat dilakukan secara optimal (Prodjosoemanto, 2006).

Sejauh ini studi mengenai aktivitas pertambangan telah menimbulkan dampak secara positif maupun negatifnya, juga menimbulkan masalah lainnya. Seperti yang ditunjukkan dalam studi Ibrahim, et al. (2015) menunjukkan bahwa masih banyak kemiskinan yang terjadi di desa sekitar tambang. Pendapatan tertinggi yang di hasilkan masyarakat berasal dari bekerja sebagai karyawan perusahaan tambang. Sedangkan hasil dari kegiatan yang berbasis perikanan semakin menurun. Kenyataaan tersebut seperti dalam studi Fachlevi, et al. (2016) bahwa masuknya aktivitas tambang memberikan dampak ekonomi sekaligus respons yang positif dari masyarakat. Namun, aktivitas tersebut menimbulkan pengaruh terhadap daerah pesisir.

Desa Laosu Jaya, Kecamatan Bondoala, Kabupaten Konawe, merupakan salah satu kawasan pesisir di sekitar area pertambangan. Penduduk Desa Laosu Jaya adalah komunitas yang hidup dipesisir pantai yang sebagian besar penduduknya menghidupi diri mereka sendiri dengan bekerja sebagai petani tambak.(Data Desa Laosu Jaya, 2017). Fenomena yang terjadi saat ini di Kecamatan Bondoala Desa Laosu Jaya adalah keadaan tambak rakyat yang sebagian wilayahnya tercemar oleh limbah pengolahan tambang nikel. Meskipun kondisi tambak yang mulai menurun namun masih ada sebagian petani tambak yang menggantungkan hidupnya dari usaha tambak tersebut.

$\begin{array}{lcr}\quad \text { Manfaat } & \text { dari } & \text { kegiatan } \\ \text { pertambangan } & \text { umumnya } & \text { dapat } \\ \text { menciptakan } & \text { lapangan } & \text { kerja, }\end{array}$
meningkatkan hasil produksi tambang, meningkatkan hasil pendapatan perusahaan, pendapatan pemerintah dan peningkatan tenaga kerja. Di samping itu juga, menimbulkan pengaruh negatif terhadap lingkungan hidup, seperti kerusakan lahan dan terjadinnya kerusakan lingkungan akibat dari aktivitas pertambangan tersebut. Adanya aktivitas pertambangan akan memberikan dampak positif sekaligus dampak negatif akibat dari kegiatan pertambangan, seperti yang telah terjadi di Kecamatan Bondoala Desa Laosu Jaya dimana masuknya perusahaan pengolahan tambang nikel diduga akan menimbulkan pengaruh, baik secara langsung maupun tidak langsung terhadap usaha tambak di sekitar aktivitas perusahaan tambang. Oleh sebab itu, perlu adanya penelitian lebih jauh mengenai seberapa besar pendapatan usaha tambak di sekitar aktivitas pertambangan. Tujuan dari penelitian ini yaitu untuk mengetahui pendapatan usaha tambak pada daerah sekitar aktivitas pertambangan di Kabupaten Konawe.

\section{Metode}

Desa Laosu Jaya, Kecamatan Bondoala, Kabupaten Konawe, Provinsi Sulawesi Tenggara menjadi lokasi penelitian ini. Pemilihan tempat dilakukan 
dengan pemahaman bahwa di Desa Laosu Jaya, merupakan salah satu sentrapenghasilikan bandeng terbesar dan terluas yang ada di Kecamatan Bondoala Kabupaten Konawe. Pemilihan lokasiinijugadidasarkan pertimbangan bahwa di Desa Laosu Jaya terdapat aktivitas tambang yang lokasinya sangat dekat dengan pemukiman masyarakat baik secara secara langsung maupun tidak langsung akan berpengaruh pada kondisi tambak. Populasidalam penelitian ini berjumlah 120 pembudidaya tambak sehingga sampel yang terpilih sebanyak 24 pembudidaya tambak dengan menggunakan rumus yang dikemukan oleh Arikunto (2006). Pengambilan sampel acak sederhana atau random sampling digunakan untuk menentukan ukuran sampel dalam penelitian ini. Data yang terkumpul selanjutnya diteliti secara deskriptif kuantitatif dengan menggunakan rumus.:

$$
\mathrm{TR}=\mathrm{P} \cdot \mathrm{Q}
$$

Keterangan:TR = Total Revenue (Total Penerimaan) (Rp), $\mathrm{P}=$ Price (Harga jual) $(\mathrm{Rp}), \mathrm{Q}=$ Quantity(Jumlah produksi) $(\mathrm{Kg})$

Keseluruhan total biaya yang dikorbankan dalam melakukan kegiatan

Tabel 1. Karakteristik Responden

\begin{tabular}{|c|c|c|c|}
\hline No & Karakteristik & Jumlah Petani & Persentase \\
\hline \multirow[t]{4}{*}{1.} & Umur (Tahun) & & \\
\hline & $0-14$ & - & - \\
\hline & $15-54$ & 19 & 79,17 \\
\hline & $>54$ & 5 & 20,83 \\
\hline \multirow[t]{5}{*}{2.} & Pendidikan & & \\
\hline & SD & 12 & 50.00 \\
\hline & SMP & 8 & 33,33 \\
\hline & SMA & 3 & 12,50 \\
\hline & Sarjana & 1 & 4,17 \\
\hline \multirow[t]{4}{*}{3.} & Pengalaman Berusahatani (Tahun) & & \\
\hline & $<5$ & - & - \\
\hline & $5-10$ & 2 & 8,33 \\
\hline & $>10$ & 22 & 91,67 \\
\hline \multirow[t]{4}{*}{4.} & Anggota Keluarga (Jiwa) & & \\
\hline & $\leq 2$ & 5 & 20,83 \\
\hline & 3-4 & 16 & 26,67 \\
\hline & $\geq 5$ & 3 & 12,50 \\
\hline
\end{tabular}

produksi ikan bandeng dapat dihitnung dengan menjumlahkan biaya variabel dengan biaya tetap menggunakan rumus:

$$
\mathrm{TC}=\mathrm{TV}+\mathrm{TF}
$$

Keterangan: $\mathrm{TC}=$ Total Cost $($ Total Biaya) $(\mathrm{Rp}), \mathrm{TV}=$ Total Variabel Cost $($ Total Biaya Variabel) $(\mathrm{Rp}), \mathrm{TF}=$ Total Cost (Total Biaya Tetap) $(\mathrm{Rp})$

Pendapatan yang diperoleh pembudidaya tambak dihiting dengan cara mengurangkan keseluruhan total penerimaan dengan total biaya dengan menggunakan rumus:

$$
\mathrm{I}=\mathrm{TR}-\mathrm{TC}
$$

Keterangan: $\mathrm{I}=$ Income (Pendapatan) $(\mathrm{Rp}), \mathrm{TR}=$ Total Revenue $($ Total Penerimaan) $(\mathrm{Rp}), \mathrm{TC}=$ Total Cost $($ Total Biaya) (Rp)

\section{Hasil Dan Pembahasan Karakteristik Responden}

Karakteristik responden afllalah objek atau profil penelitian yang dapat menggambarkan hasil penelitian. Karakteristik responden dalam penelitian ini meliputi umur, tingkat pendidikan, pengalaman berusaha tambak dan jumlah tanggungan keluarga. 
Berdasarkan Tabel 1 menunjukkan bahwa karakteristik responden dilihat dari segi umur berada pada usia prosuktif yaitu sebanyak 19 pembudidaya tambak atau sebesar 79,17\% dan kategori umur diatas 54 tahun sebanyak 5 pembudidaya tambak dengan persentase sebanyak 20,83\% dan responden yang berada pada usia belum prosuktif tidak ada. Hal ini dapat disimpulkan bahwa kemampuan fisik pelaku usaha tambak di Desa Laosu Jaya masih dalam kondisi produktif, sehingga dapat dikatakan bahwa petani tambak masih memiliki etos kerja yang tinggi dalam upaya peningkatan produksi. Oleh karena itu, bila ditinjau dari segi umur maka akan memberikan hasil produksi dan pendapatan yang lebih tinggi terhadap usaha tambak ikan bandeng yang dikelola. Hal ini sejalan dengan penelitian yang dilakukan menunjukkan bahwa petani yang berada pada jenjang usia produktif lebih potensial dalam melaksankana aktivitas usahataninya yang mampu bekerja dalam memenuhi kebutuhan ekonomi keluarganya dengan dengan cara berfikir, tingkat kematangan atau tingkat emosionalnya sudah cukup baik dalam mengembangkan usahataninya. Lebih lanjut Effendy, et al.(2019) juga menyatakan bahwa usia produktif petani juga memiliki potensi dalam berpatisipasi untuk mengembangkan kegiatan usataninya.

$$
\text { Tingkat pendidikan dalam }
$$
penelitian ini adalah jenjang pendidikan yang pernah dilakukan atau di ikuti oleh responden yaitu pembudidaya tambak ikan bandeng. Tingkat pendidikan pembudidaya tambak cukup bervariasi. Dilihat pada jenjang pendidikan SD merupakan persentase tertinggi yaitu sebanyak $50 \%$ atau sebanyak 12 responden. Di susul tingkat pendidikan SMP sebanyak 8 responden dengan persentase $33,33 \%$ dan jenjang pendidikan sarjana merupaka kategori paling sedikit sebanyak 1 responden dengan persentase $4,17 \%$. Hal ini dapat disimpulkan bahwa sebagian responden memiliki jenjang pendidikan yang rendah. Oleh sebab itu, sejak dahulu pembudidaya tambak mengandalkan pengalaman yang turun temurun dalam melakukan usaha budidaya ikan bandeng Tingkat pendidikan yang rendah akan mempengaruhi pengetahuan pembudidaya dalam mengelola usaha budidaya bandeng, namun seiring dengan bertambahnya pengalaman yang dimiliki akan meningkatkan kemampuan dan keterampilan mereka dalam mengelola usaha budidaya bandeng. Semakin meningkatnya pendidikan petani maka semakin tinggi pula pengetahuan yang dimiliki pembudidaya tambak dan lebih leluasa dalam memcari suatu informasi untuk pengembangan usahanya dan lebih menyaring informasi yang akan diterima. Hal ini sejalan dengan penelitian Adnan (2004)menyatakan bahwa tingkat pendidikan adalah salah satu faktor penunjang dalam menentukan keberhasilan usahatani karena dengan pendidikan yang baik akan mempengaruhi dalam hal bekerja, adopsi tekonogi dan pemeliharaan terhadap organisme yang dibudidayakan. Lebih lanjut Mokodongan, et al. (2016)menyatakan bahwa semakin tingginya pendidikan seseorang akan lebih cepat memahami perkembangan teknologi dan lebih mudah menyerap informasi yang berkaitan dengan kegiatan usahanya.

Pengalaman berusaha tambak adalah jumlah tahun yang dilalui oleh pembudidaya tambak sebagai proses belajar dalam melakukan kegiatan usaha tambak. Berdasarkan hasil wawancara dilapangan menunjukkan bahwa sebagian besar responden berpengalaman dalam melakukan usaha tambak ikan bandeng. Persentase tertinggi sebanyak $91,67 \%$ atau sebanyak 22 responden dengan kategori berpengalaman. Kategori cukup berpengalaman sangat sedikit yaitu sebanyak 2 responden dengan persentase $8,33 \%$ sedangkan kategoti tidak berpengalaman tidak ada. Hubungan pengalaman berusahatani dengan jumlah 
produksi yang dihasilkan memiliki hunungan yang positif diamana petani yang memiliki pengalaman usaha akan lebih dinamis dalam mengatasi masalah usahataninya (Sutarto, 2012).

Jumlah tanggungan keluarga oleh pembudidaya tambak di Desa Laosu Jaya sangat bervariasi. Jumlah tanggungan keluarga $\leq 2$ orang berjumlah 5 responden dengan persentase $20,83 \%$, disusul jumlah tanggungan antara 3-4 orang merupakan jumlah tertinggi sebanyak 16 responden dengan persentase $26,67 \%$ sisanya jumlah tanggungan keluarga $\geq 5$ orang sebanyak 3 responden memiliki persentase sebesar $12,5 \%$. Hal ini dapat disimpulkan bahwa jumlah tanggungan keluarga oleh pembudidaya tambak di Desa Laosu Jaya berkisar 1-7 orang. Menurut Purwanto (2018) tolak ukur kesejahteraan keluarga dilihat dari banyaknya jumlah tanggungan keluarga di ikuti dengan semakin meningkatnya jumlah pendapatan keluarga. Lebih lanjut Annisa dan Lamusa (2014)menyatakan bahwa besarnya jumlah tanggungan keluarga ikut mempengaruhi terhadap aktivitas kegiatan ushatani, semakin meningkatnya tanggungan keluarga akan berpengaruh terhadap pemikir usahataninya. Sehingga semakin tinggi pula interaksi di dalamnya. Disisi lain, semakin meningkatnya tanggungan keluarga semakin meningkat pula biaya yang dikorbankan, sehingga pendapatan yang diperoleh dari usahtanu juga semakin kecil.

\section{Biaya Produksi Usaha Tambak Ikan Bandeng}

Biaya produksi dalam kegiatan usaha tambak ikan bandeng adalah semua keluaran yang dikeluarkan saat melakukan usaha tambak. Biaya produksi usaha tambak ikan bandeng terdiri dari jumlah biaya tetap ditambah dengan jumlah keseluruhan biaya variabel. Biaya tetap merupakan biaya yang besarnya tidak berpengaruh pada jumlah produksi yang dihasilkan dalam satu kali produksi(Tuwo, 2011).Yang termaksud biaya tetap dalam usaha tambak bandeng teridiri dari biaya pajak lahan dan penyusutan peralatan. Sedangkan biaya variabel adalah biaya yang jumlah berubah sebanding dengan peningkatan jumlah produksi(Tuwo, 2011).Rata-rata penggunaan jumlah biaya tetap dan jumlah biaya variabel oleh pembudidaya tambak dalam satu kali musim panen dapat dilihat pada Tabel 2.

Tabel 2. Rata-rata biaya variabel dan biaya tetap pada usaha tambak ikan bandeng di Desa Laosu Jaya Kecamatan Bondoala Kabupaten Konawe

\begin{tabular}{ccc}
\hline No & \multicolumn{1}{c}{ Komponen biaya (Rp) } & Jumlah (Rp/Mp) \\
\hline 1. & Biaya Variabel & 321.667 \\
& a. Benih & 445.000 \\
b. Pupuk & 460.000 \\
c. Pakan & 209.375 \\
d. Pestisida & 545.313 \\
e. Tenaga Kerja & 1.981 .354 \\
2. Total biaya variabel (Rp/Mp) & \\
Biaya Tetap & 212.132 \\
& a. Penyusutan peralatan & 226.667 \\
& b. Pajak lahan (Rp/Mp) & 438.799 \\
\hline
\end{tabular}

Sumber: data primer diolah, 2021

Pada Tabel 2 kombinasi harga benih, pupuk, pakan, pestisida, dan tenaga kerja membentuk biaya variabel rata-rata sebesar Rp1.981.354/Mp. Penggunaan biaya variabel yang paling umum adalah biaya tenaga kerja. Hal ini dikarenakan 
petani budidaya perikanan menggunakan tenaga kerja luar dalam sistem pengelolaan lahan, penebaran benih, dan pemanenan.. Rata-rata biaya yang dikorbankan oleh pembudidaya tambak sebesar Rp545.313/Mp. Hal ini sejalan dengan penelitian Asriany (2014)menyatakan bahwa biaya terbesar dalam usaha tambak ikan bandeng adalah pada penggunaan tenaga kerja dengan rata-rata biaya yang dikorbankan sebesar Rp1.235.240/Ha/Mp.

Penggunaan pakan merupakan biaya terbesar kedua setelah tenaga kerja. Hal ini dikarenakan petani menggunakan pakan tambahan untuk mebantu perkembangan ikan bandeng akibat adanya aktivitas tambang disekitar lokasi tambak. Hal ini sejalan sengan penelitian Darmawan (2018)menyatakan bahwa usaha budiaya ikan bandeng memerlukan biaya produksi yang cukup besar terutama dalam pengdaan pakan ikan bandeng yang dapat mempengaruhi hasil produksi.

Biayabenih merupakan biaya yang selalu ada dalam setiap kegiatan budidaya ikan bandeng. Hal ini dikarenakan benih sebagai sumber utama produksi ikan bandeng. Biaya rata-rata yang dikorbankan petani sebesar Rp321.667/Mp. Biaya penggunaan pestisida sebesar Rp209.375/Mp merupakan korbanan terendah yang dikelurkan oleh petani, karena pestisida yang digunakan dalam budidaya ikan bandeng hanya sedikit mengigat penggunan pestisida yang berlebihan bisamenimbulkan dampak terhadap kualitas air ikan bandeng. Hal ini sejalan dengan penelitian Scholz (2012)menyatakan bahwa pestisida yang diaplikasikan akan hanyut ke ekosistem akuatik dan beracu bagi ikan bandneg da organisme non target. Penggunaan pestisisda yang berlebihan, akan menyebabkan terjadinya penurunan populasi spesies ikan bandeng.

Pada Tabel 2 menunjukkan ratarata biaya tetap yang digunakan oleh pembudidaya tambak sebesar Rp438.799/Mp, yang merupakan keseluruhan penjumlahan biaya penyusutan perlatan dan biaya pajak lahan. Berdasarkan hasil wawancara dilapangan bahwa biaya pajak lahan yang terjadi saat ini di Desa Laosu Jaya terjadi peningkatan akibat adanya aktivitas tambang. Hal tersebut menambah beban biaya yang dikeluarkan oleh pembudidaya tambak. Hal ini sejalan dengan penelitian Hasriani (2017)menyatakan bahwa salah satu biaya yang mengalami penigkatan akibat masuknya perusahaan tambang terjadi pada biaya pajak lahan. Biaya penyusutan peralatan dalam usaha tambak ikan bandeng meliputi penyusutan rumah jaga, pintu tambak, jaring, terpal, gabus, keranjang dan penyusutan ember. Untuk menghitung biaya penyusustan dengan cara nilai beli dikurangi dengan nilai sisa dibagi dengan umur ekonomis. Nilai sisa adalah niali alat itu sendiri yang tidak dipergunakan atau sama dengan nol (Suratiyah, 2015)

\section{Penerimaan Usaha Tambak Ikan Bandeng}

Penerimaan dalam usaha tambak ikan bandeng diperoleh dari penjualan ikan bandeng. Besar kecilnya penerimaan yang diperoleh dipengaruhi dari hasil produksi dan harga jual. Demikian, jika hasil produksi ikan bandeng tinggi dan harga jualnya juga tinggi makan penerimaan yang diperoleh juga kan tinggi sebaliknya jika hasil produksi tinggi ataupun rendah tetapi harga jualnya rendah maka hasil penerimaanya juga rendah.

Tabel 3. Rata-rata penerimaan usaha tambak ikan bandeng di Desa Laosu Jaya Kecamatan Bondoala Kabupaten Konawe tahun 2021

\begin{tabular}{cccc}
\hline No & Uraian & Satuan & Nilai \\
\hline 1 & Produksi & $\mathrm{Kg} / \mathrm{Mp}$ & 425 \\
2 & Harga & $\mathrm{Rp} / \mathrm{Kg}$ & 20.000 \\
\hline & Penerimaan & $\mathrm{Rp} / \mathrm{Mp}$ & 8.500 .000 \\
\hline
\end{tabular}

Sumber: Data Primer Diolah, 2021 
Pada Tabel 3 menunjukkan rata-rata produksi ikan bandeng dalam satu kali produksi sebesar $425 \mathrm{Kg} / \mathrm{Mp}$ dengan harga jual rata-rata sebesar $\mathrm{Rp} 20.000 / \mathrm{Kg}$ maka diperoleh penerimaan sebesar Rp8.500.000/Mp. Tinggi rendahnya penerimaan yang diperoleh petani tambak ditentukanoleh jumlah produksi ikan bandeng yang dihasilkan serta harga ikan bandeng saat itu. Berdasarkan hasil wawancara dilapangan menunjukkan bahwa produksi ikan bandeng yang dihasilkan saat ini mengalami penurunan. Penurunan jumlah produksi ikan bandeng disebakan aktivitas tambang disekitar lokasi tambak yang mempengaruhi kualitas air akibat limah pertambangan yang tidak dikelola dengan baik. Hal ini sejalan dengan penelitianDahuri (2001)salah satu faktor yang menyebabkan tinggi dan kurang produksi termaksud gagal panen adalah semakin menurunnya kualitas air dalam melakukan sumberdaya perikanan tambak khususnya pada kawasan yang padat penduduk dan tingginya pembangunan industri.

Hasil produksi ikan bandeng yang optimal menurut (Achmad et al. 2011) menyatakan bahwa usaha pembesaran ikan bandeng menghasilkan rata-rata produksi sebesar 500-1.000 $\mathrm{Kg} / \mathrm{Ha} / \mathrm{Mp}$. Hal ini berbeda dengan hasil temuan dilapangan bahwa produksi ikan bandeng menghasilkan produksi rata-rata sebesar $425 \mathrm{Kg} / \mathrm{Mp}$. Meskipun hasil produksi yang dihasilkan semakin menurun tetapi produksi yang dihasilkan termaksud dalam kategori baik jika dibandingkan dengan

Tabel 4. Rata-rata pendapatan petani tambak ikan bandeng di Desa Laosu Jaya Kecamatan Bondoala Kabupaten Konawe Tahun 2021

\begin{tabular}{clcc}
\multicolumn{2}{c}{ Bondoala Kabupaten Konawe Tahun 2021} & & \\
\hline No & \multicolumn{1}{c}{ Uraian } & Satuan & Nilai \\
\hline 1 & Total Penerimaan (TR) & $(\mathrm{Rp} / \mathrm{Mp})$ & 8.500 .000 \\
2 & Total Biaya (TC) & $(\mathrm{Rp} / \mathrm{Mp})$ & 2.420 .153 \\
\hline & Pendapatan $(\mathrm{Pd})$ & $(\mathrm{Rp} / \mathrm{Mp})$ & 6.079 .847 \\
\hline
\end{tabular}

Sumber: Data Primer Diolah, 2021 Tamiang. Hal ini sejalan dengan penelitian Indra dan Susilo (2017) bahwa produksi bandeng di Kabupaten Aceh Tamiang adalah sebesar 351,66 Kg/Ha.

Adanya aktivitas tambang di sekitar desa Laosu Jaya membuat harga jual ikan bandengmengalami peningkatan.Peningkatan harga ikan bandeng di lokasi penelitian dikarenakan lokasi penelitianberada di sekitar lokasi aktivitas tambangyang sebagian besar tenaga kerjanya berasal dari China yang tinggal disekitar lokasi pertambangan. Bagi masyarakat China salah satu ikan yang kaya akan protein adalah ikan bandeng sehingga dijadikan sebagai makanan utama setiap harinya. Semakin meningkatnya peminat dari ikan bandeng membuat harga bandeng dipasaran mengalami peningkatan.

\section{Pendapatan Usaha Tambak Ikan Bandeng}

Pendapatan merupakan hasil yang diperoleh petani tambak dari penggunaan faktor-faktor produksi atau input. Pendapatan diperoleh dari keseluruhan penerimaan dikurangi dengn keseluruha total biaya selama proses produksi berlangsung. Tinggi rendahnya pendapatan yang diperoleh petani tambak di Desa Laosu Jaya tergantung pada hasil produski yang dihasilkan dan harga jual yang berlaku. Besar kecilnya pendapatan juga dipengaruhi oleh biaya penggunaan faktorfaktor produksi selama proses produksi. tambak bandeng di Kabupaten Aceh 
Pada Tabel 4 menunjukkan pendapatan petani tambak setelah produksi sebesar Rp6.079.847/Mp dalam waktu enam bulan dengan total penerimaan Rp8.500.000/Mp dan total biaya yang dikeluarkan sebesar Rp2.420.153/Mp Yusuf et al. (2014)menyatakan bahwa penerimaan pembudidaya tambak bandeng dalam satu siklus produksi dapat mencapai Rp6.800.000Ha/Mp dengan total biaya Rp3.145.000/Ha/Mp. Besar kecilnya pendpatan yang diperoleh petani tambak dalam satu kali produksi dipengaruhi oleh jumlah produksi, luas lahan dan harga jual saat itu. Pendapatan bersih yang diperoleh petani tambak telah dikurangi dengan segala biaya yang dikeluarkan selama proses produksi berlangsung. Biaya yang termaksud dalam penelitian ini adalah biaya benih, pakan, pestisidan dan penggunaan tenaga kerja. Sedangkan biaya tetap dalam penelitian ini adalah biaya penyusutan peralatan dan biaya paja lahan. Hasil penelitian dilapangan menunjukkan bahwa pendapatan rata-rata yang diperoleh petani tambak semakin menurun akibat adanya aktivitas tambang yang tidak dikelola dengan baik sehingga berdampak pada penurunan kualitas air sehingga mempengaruhi produksi ikan bandeng. Rata-rata pendapatan yang diperoleh dalam penelitian ini tidak jauh berbeda dari hasil penelitian yang dilakukan Asriany (2014); Limi (2020); Limi et al. (2020)bahwa rata-rata pendapatan yang diperoleh pembudidaya tambak bandeng yaitu sebesar Rp5.657.318/Ha/Mp. Menurut BankIndonesia (2008) pendapatan kotor pembudidaya tambak bandeng mencapai Rp9.300.000/Ha/Mp. Hal ii jelas berbeda dengan hasil penelitian dilapangan menunjukkan rata-rata besaran pendapatan tambak bandeng di Desa Laosu Jaya sebesar Rp6.079.847/Mp. Jika pendapatan dibandingkandengan Standar Upah Minimum Provinsi Sulawesi Tenggara (UMP) Tahun 2021 sebesar Rp2.552.014, pendapatan petani lebih kecil dari
UMPSulawesi Tenggara yang merupakan standar minimal pendapatan seseorang.

\section{Kesimpulan Dan Saran}

Berdasarkan hasil analisis pendapatan disimpulkan bahwa besarnya pendapatan usaha tambak ikan bandeng di Kabupaten Konawe rata-rata sebesar Rp6.078.847/Mp dalam waktu enam bulan. Bagi petani tambak dalam meningkatkan produksi agar dapat memanfaatkan faktor produksi dengan baik dan lebih memperhatikan dalam hal pemeliharaan ikan bandeng yang kualitas airnya mulai berkurang akibat adanya aktivitas tambang.

\section{Daftar Pustaka}

Adnan. (2004). Pengetahuan Sosial Menuju Indonesia Baru. Solo: PT. Tiga Serangkai Pustaka Mandiri.

Agiesta. (2017). Faktor-Faktor yang Berhubungan dengan Keputusan Petani Beralih Kemitraan dalam Berusahatani: Kasus Petani Kemitraan Tebu di PT Gunung Madu Plantataions Beralih Ke Kemitraan Ubi Kayu di Pabrik Bumi Waras. Jurnal Ilmiah Agribisnis, 5(1), 210-222.

Asriany. 2014. Analisis Pendapatan Petani Tambak Ikan Bandeng di Desa Dolako Kecamatan Bungoro Kabupaten Pangkep. Jurnal Galung Tropika. 3(1), 64-73.

Alikodra. ( 2005). Konsep Pengelolaan Wilayah Pesisir Secara Terpadu dan Berkelanjutan. Jakarta: Gramedia Pustaka Utama.

Annisa, R., danLamusa, A. (2014). Analisis Kelayakan Usaha Bandeng di Desa Dolako Mecamatan Parigi Selatan Kabupaten Parigi Moutong Agrotekbis, 2 (3), 337-342.

Arikunto. (2006). Metode Penelitian Kualitatif. Jakarta: Bumi Aksara. 
Bank Indonesia. 2008. $\begin{gathered}\text { Jurnal Agri Sai } \\ \text { Milkfish }\end{gathered}$ Cultivation Shafia Finanching pattern Direktoral Kredit, BPR dan UMKM. Bank Indonesia .

Dahuri, R. (2016). Pengelolaan Ruang Wilayah Pesisir dan Lautan Seiring Dengan Pelaksanaan Otonomi Daerah. Sosial Ekonomi Perikanan, 17 (2), , 133-145.

Effendy, D. L., Kusnady, D., Maryani, A. 2019. Accelerating Farmers' Regeneration of Chili Farmers in Garut District West Java Indonesia. Journal Of Humanities Social Studies, 8 (5),373-383.

Fachlevi, T. A., Putri, E. I. K., danSimanjuntak, S. M. H. (2015). Dampak Dan Evaluasi Kebijakan Pertambangan Batubara Di Kecamatan Mereubo. Risalah Kebijakan Pertanian dan Lingkungan, 2(2), 171-180.

Hasriani. (2017). Analisis Pendapatan Usahatani Padi Sawah Terkena Dampak Pertambangan Nikel Di Kabupaten Konawe Selatan AGRISEP, 2(3), 53-58.

Ibrahim, Ritohardoyo, \&Setiadi. (2015). Persebaran Tingkat Kemiskinan Pada Kawasan Pertambangan Emas Di Kabupaten Sumbawa Barat. PROCEEDING, 6(5), 816-823.

Indra SB dan Susilo J. 2017. Perbedaan Pendapatan Usaha Budidaya Ikan Bandeng (Chanos Chanos) Intensif Dan Non Intensif Di Kecamatan Manyak Payed Kabupaten Aceh Tamiang. Juenal Penelitian Agrismuda. 4 (2), 57-66.

Limi, M. (2020). The Analysis of Production and Income of Milkfish Cultivation in North Konawe District. Buletin Penelitian Sosial Ekonomi Pertanian Fakultas Pertanian Universitas Haluoleo, 22(1), $\quad 1 \quad-6$. doi:http://dx.doi.org/10.33772/bpso sek.v22i1.10879

Limi, M. A., Sara, L., La Ola, T., Yunus, L., Surni, Dirgantoro, M. A.,
Gafaruddin, A., Fyka, S. A., Batoa, H., \& Yusuf, E. A. A. (2020). Technical and economical analysis of milkfish farming on the coastal area of Kendari bay after sedimentation. AACL Bioflux, 13(1), 403-413.

Mokodongan, A., Rauf, R. A., danLaapo, A. (2016). Analisis Pendapatan Petani Penggarap Pada Usahatani Padi Sawah Di Desa Kaleke Kecamatan Dolo Barat Kabupaten Sigi. Agrotekbis, 4 (3), 310-315.

Prodjosoemanto. (2006). Dampak Kegiatan Pertambangan Batubara Terhadap Kondisi Sosial ekonomi Masyarakat Di Kelurahan Loa Ipuh Darat Tenggarong Kutai Kartanegara.Sosial Ekonomi Agribisnis, 2 (5), 289-298.

Purwanto. (2018). Pengaruh Jumlah Tanggungan Terhadap Tingkat Kesejahteraan Ekonomi Keluarga Pekerja K3L Universitas Padjadjaran. Jurnal Pekerjaan Sosial, 1(2), 33-43.

Pusat Data Dan Teknologi Informasi Energi Dan Sumber Daya Mineral Kementerian Energi Dan Sumber Daya Mineral. (2015). Dampak Pembangunan Smelterdi Kawasan Ekonomi Khusus Provinsi Sulawesi Tenggara.

Rahayu, Y. A. (2019). Analisis Pendapatan Dan Resiko Usaha Tambak Udang Windu Udang Vaname di kecamatan Pasir Sakti Kabupaten Lampung. Juranal Agribisnis Perikanan, 6(2), 22-35.

Scholz. (2012). A Perspective on Modern Pesticides, Pelagic Fish Declines, and Unknown Ecological Resilience in Highly Managed Ecosystems. Bioscience, 62(4), 428-434.

Suratiyah. (2015). Ilmu Usahatani. Jakarta: Penebar Swadaya.

Sutarto. (2012). Hubungan Sosial Ekonomi Petani Dengan Tingkat Adopsi Inovasi Teknologi 
Komoditas Jagung Di Sidoharjo Wonogiri.

Jurnal Agritexts, 1(2), 1-12.

Tuwo, M. A. (2011). Ilmu Usahatani Teori dan Aplikasi Menuju Sukses. Kendari: Unhalu Press. Yusuf, Hardin, Riadi. 2014. Analisis Pendapatan Budidaya Ikan Bandeng di Kabupaten Mojokerto. Jurnal Agrisep, 4(6), 32-45. 